\title{
SOIL TESTS FOR ALUMINUM TOXICITY IN THE PRESENCE OF ORGANIC MATTER: LABORATORY DEVELOPMENT AND ASSESS- MENT
}

M. G. Whitten and G. S. P. Ritchie

ABSTRACT: Al toxicity in plants is related to the activity of $\mathrm{Al}^{3+}$ and Alhydroxy monomers in the soil solution, whereas Al complexed with ligands such as fluoride $(\mathrm{F})$, sulphate $\left(\mathrm{SO}^{2-}\right)$, and oxalate is not toxic. Estimation of toxic $\mathrm{Al}$ relies on measurement of "labile" $\mathrm{Al}$ after short contact times with colorimetric reagents or cation-exchange resins. However, shifts in equilibrium may result in non-toxic forms of $\mathrm{Al}$ reacting with the complexing agent or resin.

A series of laboratory experiments tested the degree to which labile $\mathrm{Al}$ is related to $\mathrm{Al}^{3+}$ in simplified media and compared methods of estimating labile $\mathrm{Al}$ in the presence of organic ligands and in soils. Cation-exchange resins extracted more than the theoretical concentration of $\mathrm{Al}^{3+}$ from solutions containing a range of concentrations of $\mathrm{OH}^{-}$and $\mathrm{S}_{4} 4^{2-}$. More $\mathrm{Al}$ was extracted in $15 \mathrm{~s}$ by 8 -hydroxyquinoline than by Chelex-100 from solutions of Al-humate at $\mathrm{pH} 4$. In sands which had been spiked with $\mathrm{Al}$ and organic matter, the estimation of labile $\mathrm{Al}$ varied with both the method of measurement and type of extract. The cations present in commonly used soil-extracting chloride solutions can decrease the proportion of organically complexed Al. 


\section{INTRODUCTION}

An important criteria for the selection of a soil test is that the extraction method and subsequent analytical determination should extract and measure the concentration of the forms of aluminum (Al) that are correlated with reductions in plant growth. In addition, both steps of the determination should be simple and suitable for routine use. Unfortunately, these two criteria are not necessarily compatible when soil tests are selected for $\mathrm{Al}$ toxicity.

With respect to the first criteria, research has indicated that Al toxicity is related to the activity of $\mathrm{Al}^{3+}$ and Al-hydroxy monomers in the soil solution, whereas $\mathrm{Al}$ complexed with ligands such as fluoride $(\mathrm{F})$, sulphate $\left(\mathrm{SO}_{4}{ }^{2}\right)$ and oxalate is not toxic $(1,2,3)$. Nuclear magnetic resonance (NMR) is the only truly direct method of measuring the concentration of $\mathrm{Al}^{3+}$ without disturbing the equilibrium. However, NMR lacks the sensitivity required to measure $\mathrm{Al}^{3+}$ at the concentrations thought to be marginally toxic to plants $(<50 \mu \mathrm{M})$. The next best alternative is to use indirect methods which measure the proportion of $\mathrm{Al}$ which reacts with a colour-forming complexing reagent (eg., 8-hydroxyquinoline, pyrocatechol violet) or a cation-exchange resin during a short contact time. These estimates of $\mathrm{Al}$ are often referred to as "labile $\mathrm{Al}^{\prime}$ and are considered to be correlated with the concentration $\mathrm{Al}^{3+}$ and Al-hydroxy monomers. Their main disadvantage appears to be that they disturb the Al equilibrium in solution and the complexing agent or resin reacts with forms of $\mathrm{Al}$ that are not toxic to plants. Nevertheless, they remain one of the only options available and therefore it is necessary to assess whether different analytical methods are capable of estimating a concentration of $\mathrm{Al}$ that is correlated with toxic $\mathrm{Al}$.

Recent work has shown the importance of soluble organic ligands in controlling the concentration of $\mathrm{Al}^{3+}(3,4)$. However, in order to determine whether an analytical method is capable of distinguishing between organically complexed $\mathrm{Al}$ and free $\mathrm{Al}$, it is necessary to have soils in which the extent of such complexing can be established by some independent means. This problem can be 
partially overcome by using pure solutions of humic acids (4), but caution should be exercised in extrapolating these results to soil solutions which may contain other cations and anions. Sand-peat mixtures which are less refined than humic acid may provide a link between pure solutions and natural soils. In such mixtures, the organic matter is from a common source and therefore a measure of soluble carbon (C) can be used as an indicator of the amount of organiccomplexing ions in solution if one assumes complexing capacity is proportional to the concentration of soluble $\mathrm{C}$. Even though absolute complexing cannot be determined, relative complexing can be estimated from soluble $\mathrm{C}$ and from knowledge of $\mathrm{pH}$ effects on complexing from pure solution studies. The $\mathrm{Al}$ extracted by an analytical method would be expected to be negatively correlated with soluble $\mathrm{C}$ as long as there was not too great an excess of either $\mathrm{Al}$ or soluble C.

Another problem with estimating toxic $\mathrm{Al}$ is the extraction method. Extraction by a large volume of a salt solution is simple and more easily adapted to routine use than extracting the soil solution. However, it is not known if the proportion of complexed $\mathrm{Al}$ extracted by salt solutions in the presence of soluble organic ligands is similar to that found in soil solutions. Moore and Ritchie (5) found that $\mathrm{Al}$ extracted by salt solutions was not a good indicator of $\mathrm{Al}^{3+}$ in soil solutions containing fluoride.

The objectives of our work were twofold. First, we sought to assess the ability of two indirect methods of estimating labile $\mathrm{Al}$, a cation-exchange resin and 8-hydroxyquinoline (8-HQ), to distinguish between uncomplexed $\mathrm{Al}$ and $\mathrm{Al}$ complexed with soluble organic ligands in pure solutions, sand-peat mixtures, and peaty sands. The second objective was to ascertain if complexed and total Al (Al-tot) extracted by $\mathrm{CaCl} 2$ and $\mathrm{LaCl}_{3}$ was correlated with that in the centrifuged soil solution. In order to achieve these objectives, we also had to develop extraction and analytical techniques that were suitable for use with soils. 


\section{MATERIALS AND METHODS}

\section{Method Development and Forms of Al Extracted by Cation-Exchange Resins:}

A column method of removing resin-extractable $\mathrm{Al}$ (Al-res) was developed and, in two experiments (A and B), compared with the stirred-suspension method of Campbell et al. (6), which is unsuitable for soil solutions because large volumes are required. The effects of the type of resin, the exchanging cation, and the presence of anions on the amount of $\mathrm{Al}$ removed by the column method were also investigated.

The columns consisted of $5 \mathrm{ml}$ Oxford autopippette tips plugged with acidwashed polyester aquarium filter and contained $\mathrm{lg}$ of moist resin. Two $5 \mathrm{~mL}$ aliquots of solution were pipetted into the column, which was then allowed to drain under gravity into an acid-washed vial after the first 10 drops of effluent were discarded. This weight of resin was found to be sufficient to remove all the $\mathrm{Al}$ from a solution of $\mathrm{AlCl} 3$ at $\mathrm{pH} 4$ with a concentration of $\mathrm{Al}$ in excess of that used in the subsequent experiments at similar flow rates. The concentration of $\mathrm{Al}$ in the samples was determined before and after contact with the resin.

The resins used were Chelex-100 (50-100 mesh, expts. A-D; 100-200 mesh, expts. E and F; Bio-Rad, California, USA) and Dowex 50W-X8 (20-50 mesh, BDH Chemicals, Poole, Dorset, UK). They were cleaned by suspending the beads in successive solutions of $1 \mathrm{M} \mathrm{NaOH}$ and $\mathrm{HCl}$, followed by deionised water. The sequence was repeated several times. The $\mathrm{H}$ form of the resin was then converted to the appropriate cationic form by suspension in successive aliquots of a solution of the chloride of $\mathrm{Ca}(0.0017 \mathrm{M})$ or $\mathrm{Zn}(0.1 \mathrm{M})$ until the solution reached the desired $\mathrm{pH}$.

Experiment A: In experiment A, we studied the effects of time and three concentrations of humic acid (HA; 0,4 , and $20 \mathrm{mg} / \mathrm{L}$ ) on the removal of $\mathrm{Al}$ from a solution at $\mathrm{pH} 4.5$ by two types of resin (Chelex-100 and Dowex 50W-X8), using the column and stirred-suspension methods. 
The humic acid was extracted from a peat soil with cold $\mathrm{NaOH}$ (7). A stock solution was prepared as described by Ritchie et al. (4) and the $\mathrm{pH}$ adjusted to 4.0 by stirring with $\mathrm{H}$-saturated Dowex 50W-X8 resin. Aliquots of 200-1000 $\mu 1$ of a $500 \mu \mathrm{M} \mathrm{AlCl} 3$ stock solution were diluted to $80 \%$ of final volume and then sufficient humic acid stock solution was added to give final concentrations of 0 , 4 , and $20 \mathrm{mg} / \mathrm{L}$ HA. The $\mathrm{pH}$ of each solution was adjusted using $0.1 \mathrm{M}$ or 0.01 $\mathrm{M} \mathrm{HCl}$ or $\mathrm{KOH}$ and then made up to volume with deionised water acidified to the same $\mathrm{pH}$. Each solution was brought in contact with the two resin types by both the column and stirred-suspension methods. Contact time in the columns was controlled by restricting the flow by attaching hypodermic needles to the tips of the columns. In the stirred-suspension method, subsamples were withdrawn through a filter attached to a syringe at intervals from 1 minute to 7 hours after adding the resin.

Experiment B: In experiment B, solutions containing three concentrations of $\mathrm{Al}$ $(20,40$, and $80 \mu \mathrm{M})$ and five of $\mathrm{HA}(0,50,100,200$, and $400 \mathrm{mg} / \mathrm{L})$, all at $\mathrm{pH}$ 4 , were reacted with Chelex-100 in columns and stirred suspensions. The experiment was a complete factorial design except that samples containing 50 $\mathrm{mg} / \mathrm{L} \mathrm{HA}$ and 20 or $80 \mu \mathrm{M} \mathrm{Al}$ were omitted. The solutions were made as described in the previous experiment. Each solution remained in the stirred suspensions for 60 minutes. In the column technique, the solutions took approximately 5 minutes to flow through the columns under gravity, giving a contact time of 15-20 seconds as calculated from the flow rate and void volume in the resin bed (8). This procedure was used in subsequent experiments.

Experiment $C$ : We studied the effect of $4 \mathrm{pHs}(4.0,4.5,4.75$, and 5.0) and five concentrations of $\mathrm{SO}_{4}^{2-}$ on the removal of $\mathrm{Al}$ from solution by two types of resin with two different exchanging cations $(\mathrm{Ca} / \mathrm{H}$ and $\mathrm{Zn} / \mathrm{H})$, using the column method. The resins and solutions were prepared as described previously. Sulphate was added to the solutions by adding aliquots of a $0.5 \mathrm{M} \mathrm{K} 2 \mathrm{SO}_{4}$ stock solution sufficient to give final concentrations of $0,500,1500,3000$, and $5000 \mu \mathrm{M}$ total $\mathrm{S}^{2} 4^{2}$. The ionic strength was adjusted to $0.015 \mathrm{M}$ in all solutions with $\mathrm{KCl}$. 
The speciation of $\mathrm{Al}$ in solution was estimated from the total concentrations and $\mathrm{pH}$ using the computer program Microql (9) and Qelios (10). The formation of $\mathrm{AlOH}^{+}, \mathrm{Al}(\mathrm{OH}) 2^{+}, \mathrm{Al}(\mathrm{OH}) 3$, and $\mathrm{AlSO}^{+}$were considered and the thermodynamic formation constants were taken from Lindsay (11).

Al-Organic Matter Reactions in Solution: Experiment D: The labile Al extracted in $15 \mathrm{~s}$ by 8 -HQ (12) from the Al-humate solutions prepared in experiment $\mathrm{B}$ was compared with the labile $\mathrm{Al}$ extracted by the column resin method described above. The 8-HQ method differed from that of James et al. (12) in that separation of the butyl acetate was aided by centrifugation and $\mathrm{Al}$ in the butyl acetate was determined by GFAAS.

Al-Organic Matter Reactions in Sand-Peat Mixtures: Experiment E: We measured soluble $\mathrm{C}, \mathrm{pH}, \mathrm{Al}$-tot, and labile $\mathrm{Al}$ (Table 1) in a sand amended with four additions of peat $(0.5 \%-4 \% \mathrm{w} / \mathrm{w})$ and six concentrations of $\mathrm{Al}, 0-200 \mu \mathrm{g} / \mathrm{g}$ (Table 1).

The sand was from the C horizon (1-2 m) of a Gavin sand, Uc2.22 (13) from the Bassendean Sand Association described by Bettenay et al. (14). The sand was mixed with peat ("Compeat", Magnet Industries, Western Australia) which had been finely ground, acid-leached, and partially neutralised with $\mathrm{KOH}$, to give sand-peat mixtures that were $0 \%, 0.5 \%, 1.0 \%, 2.0 \%$, and $4.0 \% \mathrm{w} / \mathrm{w}$ peat. Al was added to the soil as $\mathrm{AlCl}_{3}$ at $\mathrm{pH} 4$ in a volume sufficient to wet the sand-peat mixture to $18 \% \mathrm{w} / \mathrm{w}$ water content and at a concentration to achieve the rates of addition given in Table 2. The mixtures were incubated for $16 \mathrm{~h}$ at $60^{\circ} \mathrm{C}$ and then dried at $60^{\circ} \mathrm{C}$ for approximately one week and divided into two equal portions. Soil solutions of approximately $\mathrm{pH} 4$ were prepared by wetting the mixtures to $18 \% \mathrm{w} / \mathrm{w}$ moisture content with dilute $\mathrm{HCl}$ or $\mathrm{KOH}$ solutions containing sufficient $\mathrm{H}^{+} / \mathrm{OH}^{-}$as estimated from $\mathrm{pH}$ buffer curves for each treatment combination. After incubating the mixtures for $16 \mathrm{~h}$, treatments were divided into five subsamples. The soil solution was extracted from one sample by the method of Gillman (15). Three subsamples were shaken with $0.0017 \mathrm{M}$ and $0.01 \mathrm{M} \mathrm{CaCl} 2$ and $0.00083 \mathrm{M}$ $\mathrm{LaCl} 3$ at a soil:liquid ratio of $1: 5$ for $1 \mathrm{~h}$. The remaining sample was shaken with 
TABLE 1: Al Additions ( $\mu \mathrm{g} / \mathrm{g}$ ) to Sand-Peat Mixtures (Expt. E) and Peaty Sands (Expt. F).

\section{Al Peaty Sands (\% Org C) Sand + peat (\% w/w) \\ $\mu \mathrm{g} / \mathrm{g}$}

\begin{tabular}{|c|c|c|c|c|c|c|c|c|}
\hline & $\begin{array}{l}\text { Jocl B } \\
(0.2)\end{array}$ & $\begin{array}{l}\text { Gav } \\
(0.6)\end{array}$ & $\begin{array}{l}\text { Jocl } A \\
(1.2)\end{array}$ & $\begin{array}{l}\text { Mung } \\
(2.2)\end{array}$ & 0.5 & 1 & 2 & 4 \\
\hline 0 & $x$ & $\mathbf{x}$ & $x$ & $\mathrm{x}$ & $x$ & $x$ & $\mathrm{x}$ & $\mathrm{x}$ \\
\hline 0.1 & & & & & & & & \\
\hline 1 & & & & & & & & \\
\hline 2 & $\mathrm{x}$ & & $x$ & & $\mathrm{x}$ & & & \\
\hline 4 & $\mathrm{x}$ & & & $\mathrm{x}$ & $x$ & & & \\
\hline 8 & & & & & & & & \\
\hline 10 & $\mathrm{x}$ & $\mathbf{x}$ & $\mathrm{x}$ & $\mathrm{x}$ & $\mathrm{x}$ & $\mathrm{x}$ & $\mathrm{x}$ & $\mathrm{x}$ \\
\hline 15 & $\mathrm{x}$ & & & & & & & \\
\hline 20 & $\mathbf{x}$ & $\mathbf{x}$ & $\mathrm{x}$ & $\mathrm{x}$ & $\mathrm{x}$ & $x$ & $x$ & $\mathbf{x}$ \\
\hline 40 & & $\mathrm{x}$ & & & & & & \\
\hline 50 & & & $\mathbf{x}$ & $x$ & $\mathrm{x}$ & $\mathrm{x}$ & $\mathrm{x}$ & $\mathrm{x}$ \\
\hline 100 & & $\mathbf{x}$ & $\mathbf{x}$ & $\mathrm{x}$ & & $\mathrm{x}$ & $\mathrm{x}$ & $\mathrm{x}$ \\
\hline 200 & & $\mathrm{x}$ & & & & $\mathrm{x}$ & $\mathrm{x}$ & $\mathrm{x}$ \\
\hline
\end{tabular}

TABLE 2. Analyses for Each Type of Extract of the of Sand-Peat Mixtures (Expt. E) and Peaty Sands (Expt. F).

\begin{tabular}{|c|c|c|c|c|c|}
\hline \multirow[t]{4}{*}{ Analysis } & \multirow{4}{*}{$\begin{array}{l}\text { Soil } \\
\text { Solution }\end{array}$} & \multicolumn{4}{|c|}{ Extracts } \\
\hline & & \multicolumn{3}{|c|}{$1: 5$} & \multirow{3}{*}{$\frac{1: 20}{\mathrm{BaCl}_{2}}=$} \\
\hline & & \multicolumn{2}{|c|}{$\mathrm{CaCl}_{2}$} & \multirow{2}{*}{$\begin{array}{c}\mathrm{LaCl} 3 \\
0.00083 \mathrm{M}\end{array}$} & \\
\hline & & $0.01 \mathrm{M}$ & $0.0017 \mathrm{M}$ & & \\
\hline Al-res & $\mathrm{x}$ & & & & \\
\hline $\mathrm{Al}-\mathrm{HQ}$ & $\mathrm{x}$ & $\mathrm{x}$ & $\mathrm{x}$ & $\mathrm{x}$ & \\
\hline Al-tot & $\mathbf{x}$ & $\mathrm{x}$ & $\mathrm{x}$ & $\mathrm{x}$ & $\mathrm{x}$ \\
\hline Org-C & $\mathrm{x}$ & $\mathrm{x}$ & $\mathrm{x}$ & $\mathbf{x}$ & $\mathrm{x}$ \\
\hline $\mathrm{pH}$ & $\mathrm{x}$ & $\mathrm{x}$ & $\mathrm{x}$ & $\mathrm{x}$ & $x$ \\
\hline
\end{tabular}


$0.1 \mathrm{M} \mathrm{BaCl} 2$ at a soil:liquid ratio of 1:20 for $1 \mathrm{~h}$. The soil solution and the four extracts were then centrifuged, filtered $(0.45 \mu \mathrm{m})$, and analysed for $\mathrm{pH}, \mathrm{Al}$-tot, $\mathrm{Fe}$, $\mathrm{Ca}$, and $\mathrm{C}$ by ICPES and labile $\mathrm{Al}$-res using Chelex-100 in the $\mathrm{Mg} / \mathrm{H}$ form and Al-HQ (Table 2).

Al-Organic Matter Reactions in Soils: Experiment F: We measured pH, soluble C, Al-tot , Al-res, and Al-HQ in five soils amended with six rates of $\mathrm{Al}(0-200$ $\mu \mathrm{g} / \mathrm{g}$, Table 2). The soils were four peaty sands, naturally acidic ( $\mathrm{pH} \mathrm{3.5-4.6} \mathrm{in} \mathrm{1:5}$ $0.01 \mathrm{M} \mathrm{CaCl}$ ) with low $\mathrm{CEC}(4-8 \mathrm{cmolc} / \mathrm{kg})$ and a range of organic $\mathrm{C}$ contents (Table 2). They have been described in detail by Bettenay et al. (14) and Smith (16). The preparation of the soils and their subsequent extraction and analysis were the same as in the previous experiment.

Chemical Analyses: Al-tot and $\mathrm{Al}$ in solutions which had been in contact with ion exchange resin were measured by graphite furnace atomic absorption spectrophotometry (GFAAS) or inductively coupled plasma emission spectrophotometry (ICPES). The $\mathrm{pH}$ was determined with a combination electrode using a Beckman $\emptyset 71$ or an Orion EA940 $\mathrm{pH}$ meter.

\section{RESULTS}

Experiment A: In solutions containing $5 \mu \mathrm{M} \mathrm{Al}$ at $\mathrm{pH} 4.5$, stirred suspensions of both Chelex-100 and Dowex 50W-X8 removed most of the Al from solutions with no humic acid within 60 minutes (Figure 1a, b). However, in the presence of $20 \mathrm{mg} / \mathrm{L} \mathrm{HA} \mathrm{(Al:COOmolc} \mathrm{ratio} \mathrm{1:4),} \mathrm{uptake} \mathrm{of} \mathrm{Al}$ by the resins continued for at least 7 hours (Figure lc). The rate of uptake by the Chelex-100 resin diminished from approximately $1 \mu \mathrm{M} / \mathrm{h}$ in the first hour to an average of approximately 0.1 $\mu \mathrm{M} / \mathrm{h}$ for the last 4 hours. In the case of Dowex $50 \mathrm{~W}-\mathrm{X} 8$, the rate of uptake was approximately $0.5 \mu \mathrm{M} / \mathrm{h}$ for the first hour and an average of approximately 0.02 $\mu \mathrm{M} / \mathrm{h}$ for the last 4 hours.

Chelex-100 removed more Al from solution than did Dowex 50W-X8 when humic acid was present. For example, after 60 min Chelex-100 removed $21 \%$ of 

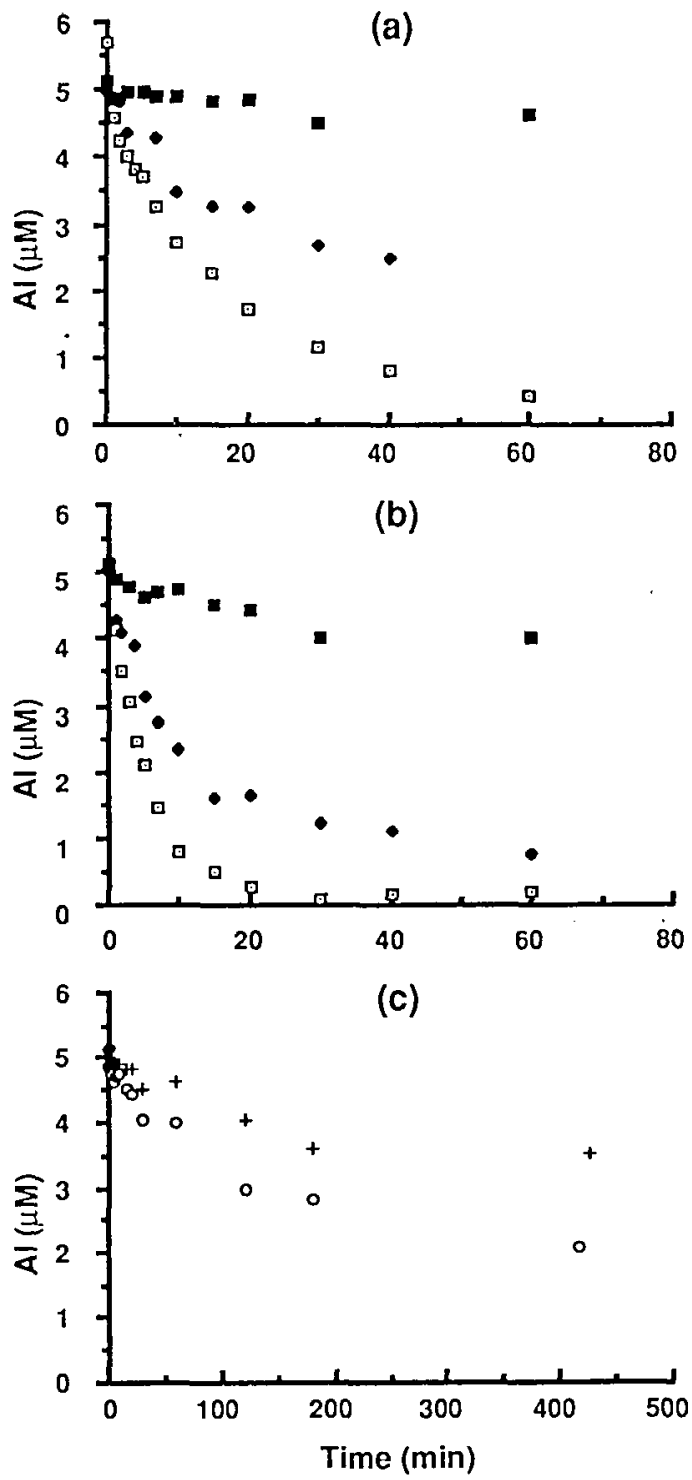

Figure 1. Removal of Al by stirred suspensions of (a) Dowex 50W-X8 and (b) Chelex-100 from a solution of $5 \mu \mathrm{M} \mathrm{Al}$ with $0 \mathrm{HA}(\varpi), 4 \mathrm{mg} \mathrm{HA} / \mathrm{L}$ $(\star)$ and $20 \mathrm{mg} \mathrm{HA} / \mathrm{L}(\boldsymbol{D})$ at intervals up to 60 minutes, and (c) over approximately 7 hours from the $20 \mathrm{mg} \mathrm{HA} / \mathrm{L}$ solution by Dowex 50W-X8 (t) and Chelex-100 (0). 
total soluble aluminum in the presence of $20 \mathrm{mg} / \mathrm{L} \mathrm{HA}$, whereas the Dowex resin removed only $10 \%$ of the $\mathrm{Al}$.

When the same solution of $\mathrm{Al}$ and humic acid as used in stirred suspensions of resin was passed through the columns of the resin, the proportion of $\mathrm{Al}$ removed (from $5 \mu \mathrm{M} \mathrm{Al}, 20 \mathrm{mg} / \mathrm{L} \mathrm{HA}$ ) by Chelex-100 at $3 \mathrm{~s}$ and Dowex $50 \mathrm{~W}-\mathrm{X} 8$ at 5-13 s (Figure 2) was similar to that removed by the stirred suspensions of Chelex and Dowex, respectively, at 60 minutes. As the contact time was increased, a greater proportion of $\mathrm{Al}$ was removed from solution.

Experiment B: $\mathrm{Al}$ removed by Chelex-100 was the same in columns with a contact time of 15-20 s as in a stirred suspension after $60 \mathrm{~min}$ (Figure 3).

Experiment $C$ : $\mathrm{Al}$ removed by both Chelex and Dowex in the $\mathrm{Ca} / \mathrm{H}$ form was independent of $\mathrm{pH}$ between 4.0 and 5.0, whereas the theoretical estimate of the concentration of $\mathrm{Al}^{3+}$ decreased fivefold (Figure 4a). Similarly, the $\mathrm{Al}$ removed by both resins did not vary as the total sulphate concentration was increased from $0-5000 \mu \mathrm{M}$, even though the theoretical estimate of $\left[\mathrm{Al}^{3+}\right]$ decreased from 46 to $2 \mathrm{O} \mu \mathrm{M}$ and $\left[\mathrm{AlSO}^{+}\right]$increased from 0-30 $\mu \mathrm{M}$ (Figure $4 \mathrm{~b}$ ). Similar results were obtained when the $\mathrm{Zn} / \mathrm{H}$ form of the resins was used.

Al-Organic Matter Reactions in Solution: Experiment D: In the comparison between methods of fractionating $\mathrm{Al}$ in synthetic solutions of $\mathrm{Al}$ and humic acid at $\mathrm{pH} 4$, there was a reasonably good correlation between $\mathrm{Al}-\mathrm{HQ}$ and $\mathrm{Al}-\mathrm{res}$ using $\mathrm{Ca} / \mathrm{H}$ Chelex-100 in the column method $\left(\mathrm{r}^{2}=0.92\right)$. The ratio of Al-HQ:Al-tot was greater than the ratio of Al-res:Al-tot, and the difference between these methods of estimating labile $\mathrm{Al}$ increased as the ratio of $\mathrm{Al}(\mu \mathrm{M}): \mathrm{C}(\mathrm{mg} / \mathrm{L})$ increased (Figure 5).

Al-Organic Matter Reactions in Sand-Peat Mixtures: Experiment E: In the soil solution, soluble $\mathrm{C}$ decreased exponentially as the additions of $\mathrm{Al}$ increased and increased with the percentage of peat present (Figure 6a). Total soluble Al remained approximately the same ( $0.5 \%$ peat) or increased slightly ( $1 \%-4 \%$ peat) as $\mathrm{Al}$ added to each mixture increased. The only exception was a sharp increase in the concentration of $\mathrm{Al}$ observed with the addition of $200 \mu \mathrm{g} / \mathrm{g} \mathrm{Al}$ to the $1 \%$ 


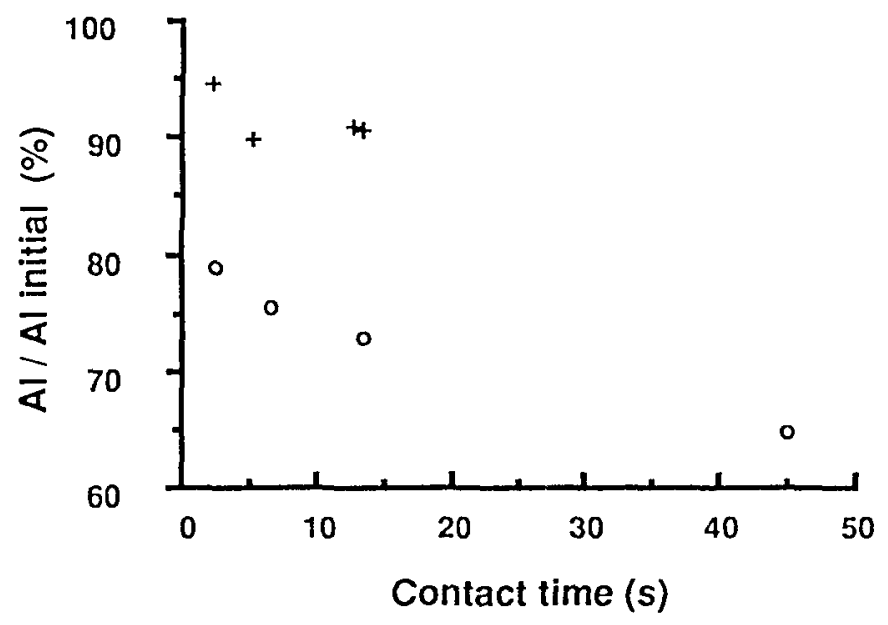

Figure 2. The effect of contact time on the proportion of $\mathrm{Al}$ removed from a solution of $5 \mu \mathrm{M} \mathrm{AlCl} 3$ at $\mathrm{pH} 4.5$ by Dowex $50 \mathrm{~W}-\mathrm{X} 8(+)$ and Chelex-100 (O) in columns.

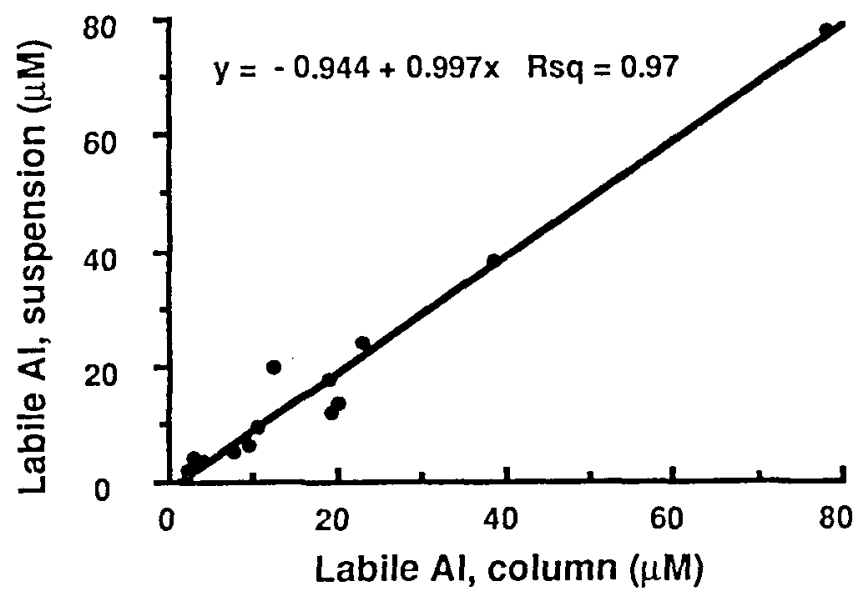

Figure 3. The relationship between $\mathrm{Al}$ removed from solutions of $\mathrm{AlCl} 3$ at $\mathrm{pH}$ 4 by Chelex- 100 with a contact time of 60 minutes in a stirred suspension and 15-20 seconds in columns. 
(a)

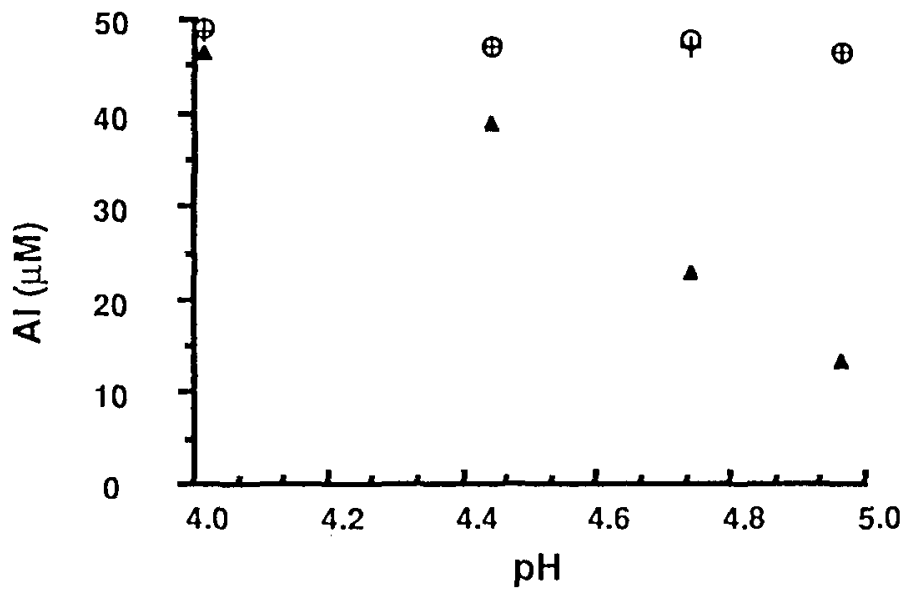

(b)

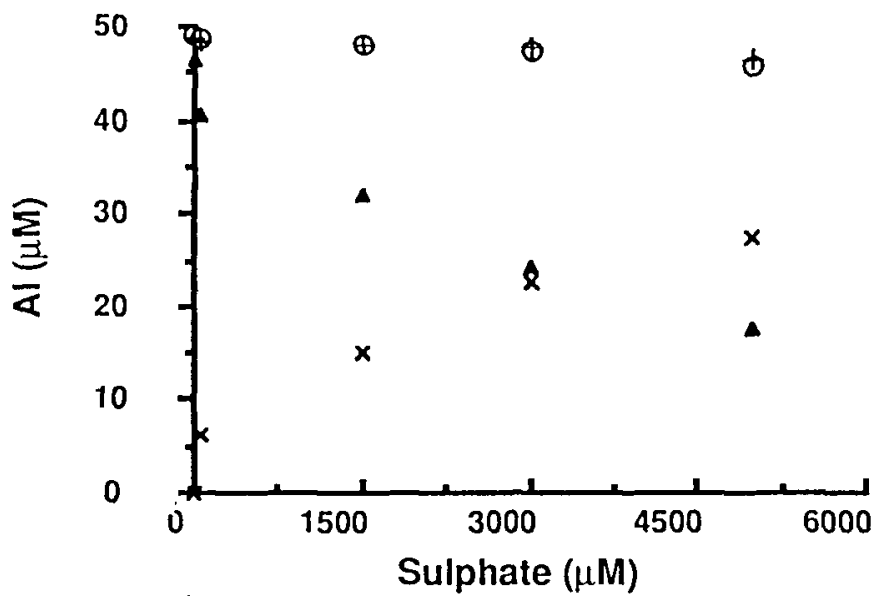

Figure 4. Labile AI $(\mu \mathrm{M})$ by Chelex-100 (O) and Dowex 50W-X8 (+) in columns and calculated concentrations $(\mu \mathrm{M})$ of $\mathrm{Al}^{3+}(\Delta)$ and $\mathrm{AlSO}^{+}$ $(\mathrm{X})$ plotted against (a) $\mathrm{pH}$ and (b) concentration of sulphate. 
(a)

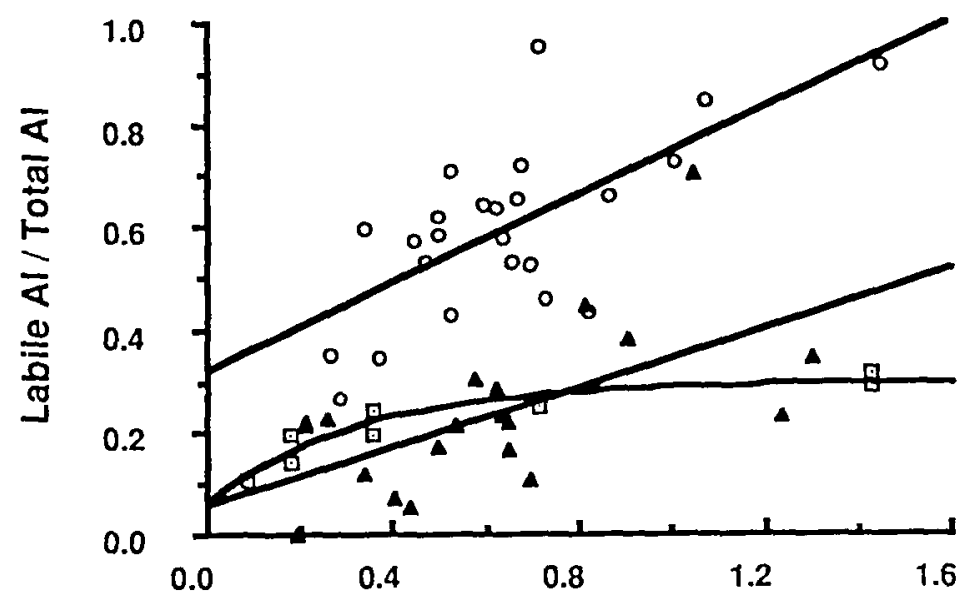

(b)

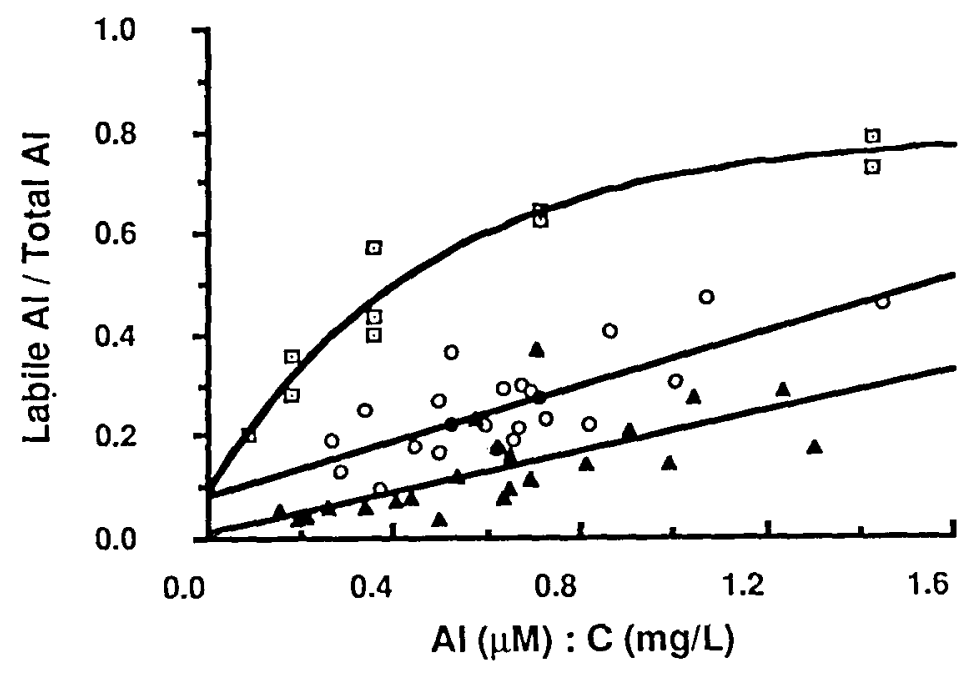

Figure 5. Labile $\mathrm{Al}(\mu \mathrm{M})$ as a proportion of total $\mathrm{Al}(\mu \mathrm{M})$ plotted against the ration of $\mathrm{Al}(\mu \mathrm{M})$ : organic $\mathrm{C}(\mathrm{mg} / \mathrm{L})$ for (a) Chelex-100 and (b) 8Hydroxyquinoline in humic acid solutions (ब), sand-peat mixtures $(\Lambda)$, and peaty sands $(0)$ at $\mathrm{pH} 4.0 \pm 0.1$ with a range of $\mathrm{Al}$ additions. 

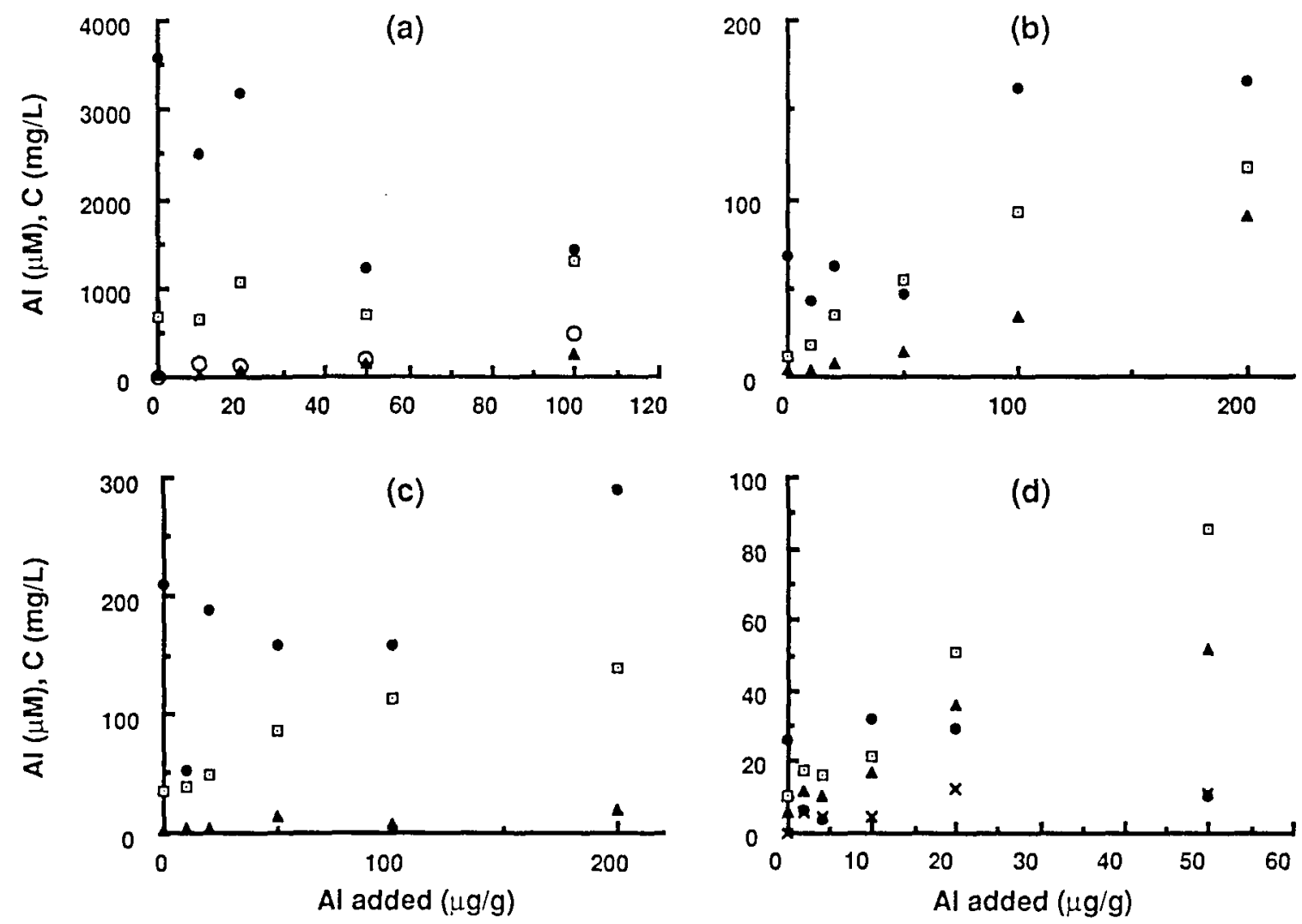

Figure 6. The effect of added $\mathrm{Al}(\mu / \mathrm{g}$ on the concentration of $\mathrm{Al}(\mu \mathrm{M})$ and $\mathrm{C}(\mathrm{mg} / \mathrm{L})$ in sand-peat mixtures: soil solution, $2 \%$ peat (a), 1:50.01 $\mathrm{M} \mathrm{CaCl} 2,2 \%$ peat (b), $1: 50.0017 \mathrm{M} \mathrm{CaCl} 2,4 \%$ peat (c) and 1.50 .00083 $\mathrm{M} \mathrm{LaCl} 3$ and 1:20 0.1 M BaCl2, $0.5 \%$ peat (d). Symbols are Al-tot ( $\square$ ). Al-res (0), Al-HQ (४), Al-tot in $\mathrm{BaCl}_{2}(\mathrm{x})$, and organic $\mathrm{C}(\bullet)$. 
peat mixture, which coincided with an unexpected decrease in $\mathrm{pH}$. Al-HQ was < $10 \%$ of Al-tot and tended to remain constant as total Al added to the sand-peat mixtures increased. Al-res was slightly greater than Al-HQ and remained constant ( $0.5 \%$ peat) or increased with $\mathrm{Al}$ added ( $1 \%-4 \%$ peat). The proportion of $\mathrm{Al}$ that was labile increased linearly with the ratio $\mathrm{Al}(\mu \mathrm{M}): \mathrm{C}(\mathrm{mg} / \mathrm{L})$ (Figure 5).

In the $\mathrm{CaCl} 2$ extracts, soluble $\mathrm{C}$ in the sand-peat mixtures with $0.5 \%$ peat and both $\mathrm{Al}$-tot and $\mathrm{Al}-\mathrm{HQ}$ in all the mixtures followed similar trends to the values found in the soil solution. At higher percentages of peat additions, however, soluble $\mathrm{C}$ varied inconsistently at the higher additions of $\mathrm{Al}$ (Figure $6 \mathrm{~b}, \mathrm{c}$ ). Soluble $\mathrm{C}$ tended to be lower in the presence of small additions of $\mathrm{Al}$ than in the presence of large amounts of $\mathrm{Al}$.

In the $\mathrm{LaCl} 3$ extracts, both $\mathrm{Al}$-tot and $\mathrm{Al}-\mathrm{HQ}$ increased with $\mathrm{Al}$ added to the sand-peat mixtures, but Al-tot increased at a greater rate than did Al-HQ (Figure 6d). Soluble $\mathrm{C}$ did not show any consistent trends with $\mathrm{Al}$ added. Al-tot in the $\mathrm{BaCl} 2$ extracts increased slightly with $\mathrm{Al}$ added at the $0.5 \%$ peat addition (Figure $6 d)$.

The concentration of Al-tot in the soil solution of the sand-peat mixtures was reasonably well correlated $\left(\mathrm{r}^{2}>0.70\right)$ with total $\mathrm{Al}$ in the 0.017 and $0.01 \mathrm{M} \mathrm{CaCl} 2$ extracts but not with Al-tot extracted by $\mathrm{La}$ and $\mathrm{BaCl} 2$ (Table 2). It was also well correlated with $\mathrm{Al}-\mathrm{res}$, and $\mathrm{Al}-\mathrm{HQ}$ in the 0.017 and $0.01 \mathrm{M} \mathrm{CaCl} 2$ and $\mathrm{LaCl} 3$ extracts (Table 2).

The concentration of Al-HQ in the soil solution was not well correlated with Al-res in the soil solution or Al-HQ in the chloride extracts (Table 2). It was, however, well correlated with $\mathrm{Al}$-tot extracted by $\mathrm{BaCl} 2$ and $\mathrm{LaCl} 3$. In contrast, Al-res was well correlated with $\mathrm{Al}-\mathrm{HQ}$ in the $\mathrm{CaCl} 2$ and $\mathrm{LaCl} 3$ extracts (Table 2) and was also well correlated with $\mathrm{Al}$-tot extracted by $\mathrm{LaCl} 3$ and $0.01 \mathrm{M} \mathrm{CaCl} 2$. Al-Organic Matter Reactions in Soils: Experiment F: Even though, the soils were all sandy by texture, the variation in $\mathrm{Al}, \mathrm{pH}$, and $\mathrm{C}$ in their soil solutions and the extracts was not always similar.

The $\mathrm{pH}$ remained at $4.0 \pm 0.1$ (Figure 7) except for Joel $\mathrm{A}$, in which the $\mathrm{pH}$ 


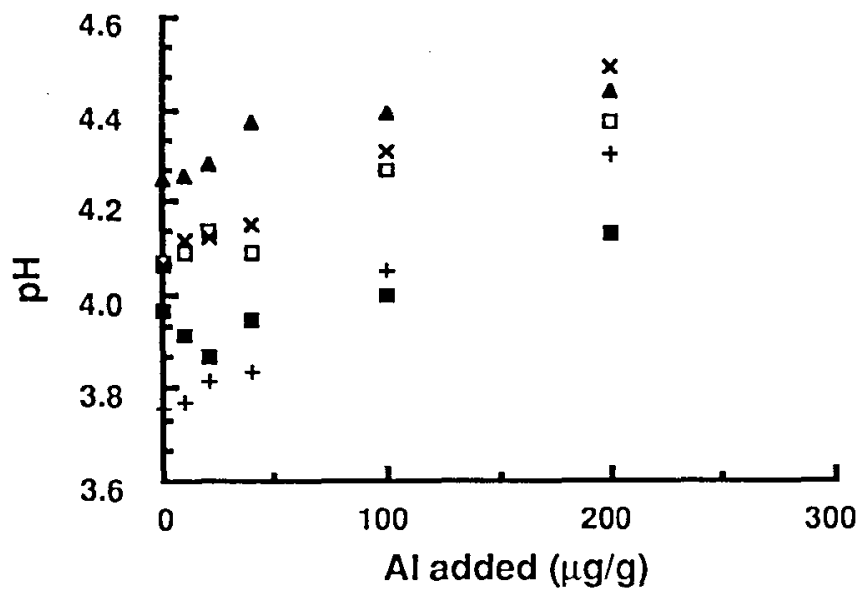

Figure 7. $\mathrm{pH}$ in the soil solution (匹), 1:5 $0.0017 \mathrm{M} \mathrm{CaCl} 2(\Delta), 1: 50.01 \mathrm{M}$ $\mathrm{CaCl}_{2}(\square), 1: 50.00083 \mathrm{M} \mathrm{LaCl} 3$, and 1:20 0.1M BaCl2 $(x)$ of Gavin peaty sand as affected by the addition of $\mathrm{Al}(\mu \mathrm{g} / \mathrm{g})$.

decreased to 3.85 at the highest $\mathrm{Al}$ addition. $\mathrm{Al}$-tot, $\mathrm{Al}$-res, and $\mathrm{Al}-\mathrm{HQ}$ in the soil solution all increased linearly as the added $\mathrm{Al}$ increased (Figure 8a), except for the Mungite soil in which they decreased initially and then became constant. The resin extracted a greater proportion of Al-tot than did the $8-\mathrm{HQ}$, and the proportion increased as the ratio $\mathrm{Al}(\mu \mathrm{M}): \mathrm{C}(\mathrm{mg} / \mathrm{L})$ increased (Figure 5). Soluble $\mathrm{C}$ tended to remain constant (Figure 8a) in all the soils or increase slightly (Joel B). In the $\mathrm{CaCl} 2, \mathrm{LaCl} 3$, and $\mathrm{BaCl}_{3}$ extracts, Al-tot increased very slightly and $\mathrm{Al}-\mathrm{HQ}$ did not change much as added $\mathrm{Al}$ increased (Figure $8 \mathrm{~b}-\mathrm{d}$ ). Soluble $\mathrm{C}$ remained constant except at the highest $\mathrm{Al}$ addition when there was a large increase in the Gavin, Joel A ( $\mathrm{LaCl} 3$ only), Joel B (0.01 M CaCl2 only), and Mungite $(0.01 \mathrm{M}$ $\mathrm{CaCl}_{2}$ and $\mathrm{LaCl}_{3}$ only) soils. The $\mathrm{pH}$ values of the extracts were all higher (except for the $\mathrm{LaCl} 3$ extracts for soils other than Joel A with $\mathrm{Al}$ added $<50 \mu \mathrm{g} / \mathrm{g}$ ) than 
(a)
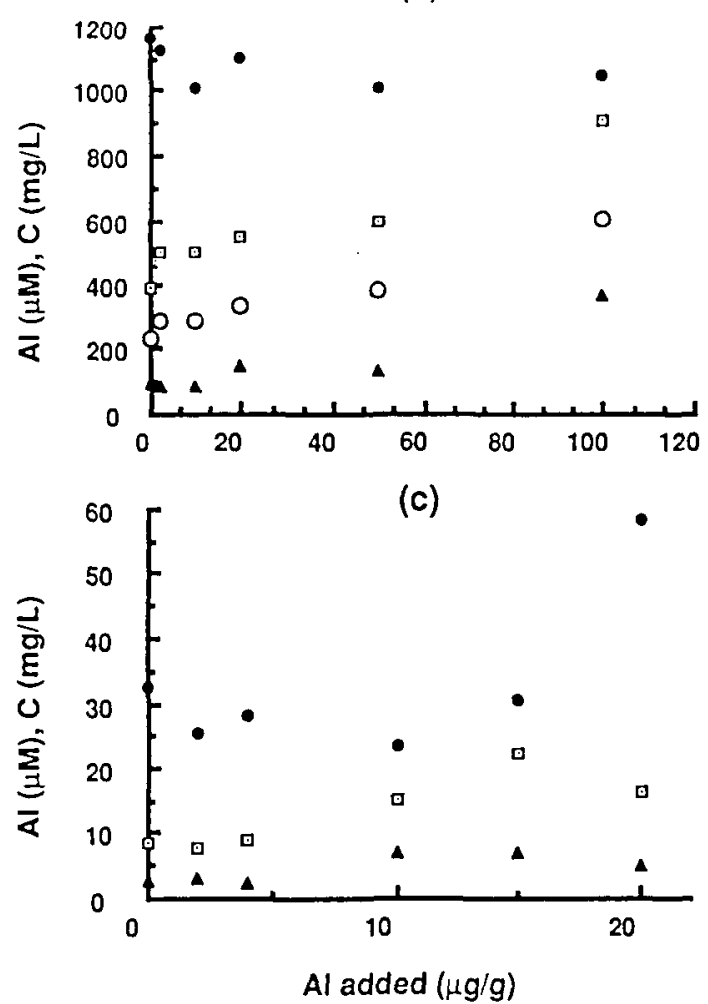

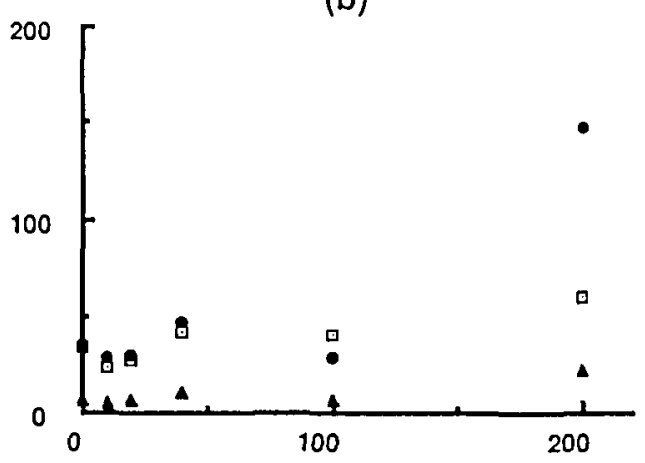

(d)

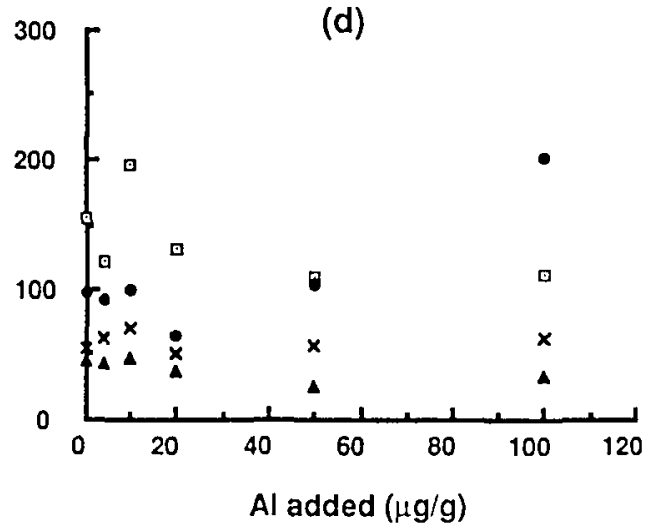

Figure 8. The effect of added $\mathrm{Al}$ on the concentration of $\mathrm{Al}(\mu \mathrm{M})$ and $\mathrm{C}(\mathrm{mg} / \mathrm{L})$ in peaty sands: soil solution, Joel $\mathrm{A}(\mathrm{a}), 1: 50.0017 \mathrm{M} \mathrm{CaCl}$, Gavin (b), 1:5 0.01 M CaCl2, Joel B (c) and 1:5 0.00083 M LaCl3 and 1:20 $0.1 \mathrm{M} \mathrm{BaCl} 2(\mathrm{~d})$. Symbols are Al-tot (口). Al-res (O), Al-HQ (४), Al-tot in $\mathrm{BaCl}_{2}(\mathrm{x})$, and organic $\mathrm{C}(\bullet)$. 
that of the soil solution and increased approximately $0.1-0.45$ units as added $\mathrm{Al}$ increased (Figure 7). For the Joel B soil, there was a large increase in $\mathrm{pH}(0.5$ 0.7 units) at the highest $\mathrm{Al}$ addition.

Al-tot in the soil solution was correlated $\left(\mathrm{r}^{2}>0.70\right)$ with Al-tot in the $0.01 \mathrm{M}$ $\mathrm{CaCl} 2, \mathrm{LaCl} 3$, and $\mathrm{BaCl} 2$ extracts and with $\mathrm{Al}-\mathrm{HQ}$ in both $\mathrm{CaCl} 2$ extracts (Table 3). It was also correlated with Al-res but not $\mathrm{Al}-\mathrm{HQ}$ in the soil solution. The latter was well correlated $\left(\mathrm{r}^{2}=0.86\right.$ ) with only one other measure of labile Al (AI-HQ in $0.01 \mathrm{M} \mathrm{CaCl} 2$ ) and was also correlated with $\mathrm{Al}$-tot in $0.01 \mathrm{M} \mathrm{CaCl} 2$ and $\mathrm{LaCl}$.

\section{DISCUSSION}

The forms of aluminum extracted by the resin and by 8 -HQ were not the same in either the humic acid or the soil solutions. In addition, the concentration of $\mathrm{Al}$ in the different forms did not change in a similar manner when $\mathrm{Al}$ or peat was added to the soils or to the sand-peat mixtures. Labile Al in the extracts was not well correlated with labile $\mathrm{Al}$ in the soil solution, possibly because the cation of the extracting solutions precipitated soluble $C$ under certain circumstances. Therefore, no uniform relationship was observed between Al-HQ in the soil solution and that in any of the extracts. In contrast, Al-tot in the soil solution was correlated with Al-tot in the extracts, but this measure of $\mathrm{Al}$ is not necessarily related to plant growth.

Method Development: Columns of $\mathrm{Ca} / \mathrm{H}$ saturated Chelex-100 could be substituted for the more time-consuming and cumbersome stirred-suspension method of estimating rapidly labile Al, provided a contact time of $<20 \mathrm{~s}$ could be attained.

Similar results were achieved with the $\mathrm{Zn} / \mathrm{H}$ form of the resins, indicating that selective blocking of uptake of $\mathrm{Al}(\mathrm{OH})^{2+}$ and $\mathrm{Al}\left(\mathrm{SO}_{4}\right)^{+}$by the resin is not possible. This may be because these monomeric species occur between $\mathrm{Al}^{3+}$ and $\mathrm{Zn}^{2+}$ in the series of relative affinities for Chelex-100, $\mathrm{Cu}^{2+}>>\mathrm{Pb}^{2+}>\mathrm{Fe}^{3+}>\mathrm{Al}^{3+}>\mathrm{Cr}^{3+}>$ $\mathrm{Ni}^{2+}>\mathrm{Zn}^{2+}>\mathrm{Ag}^{+}>\mathrm{Co}^{2+}>\mathrm{Cd}^{2+}>\mathrm{Fe}^{2+}>\mathrm{Mn}^{2+}>\mathrm{Ba}^{2+}>\mathrm{Ca}^{2+}>>\mathrm{Na}^{+}(17)$ or the equilibria $\mathrm{Al}^{3+}=\mathrm{Al}(\mathrm{I})^{(3-n)+}$, where $\mathrm{I}=$ inorganic ligand of valence $-n$, shifts rapidly 
TABLE 3. Correlation Matrix $\left(\mathrm{r}^{2}\right)$ for Al-tot and Labile $\mathrm{Al}$ in Different Types of Extracts for Sand-Peat Mixtures (1st row) and Peaty Sands (2nd row).

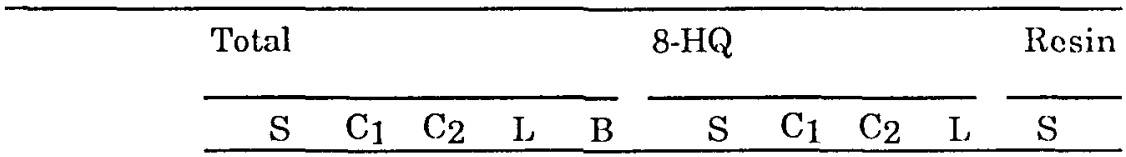

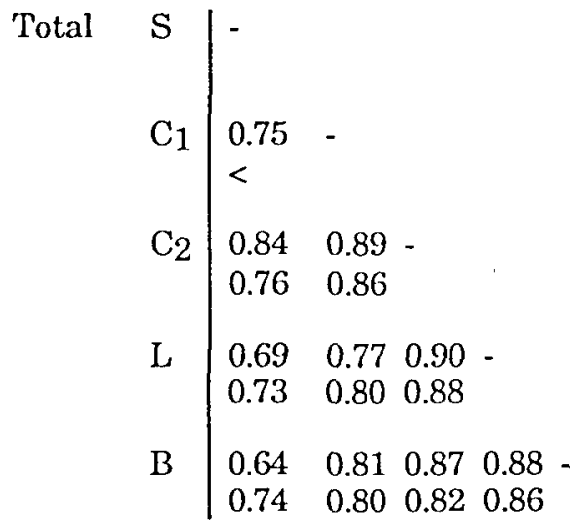

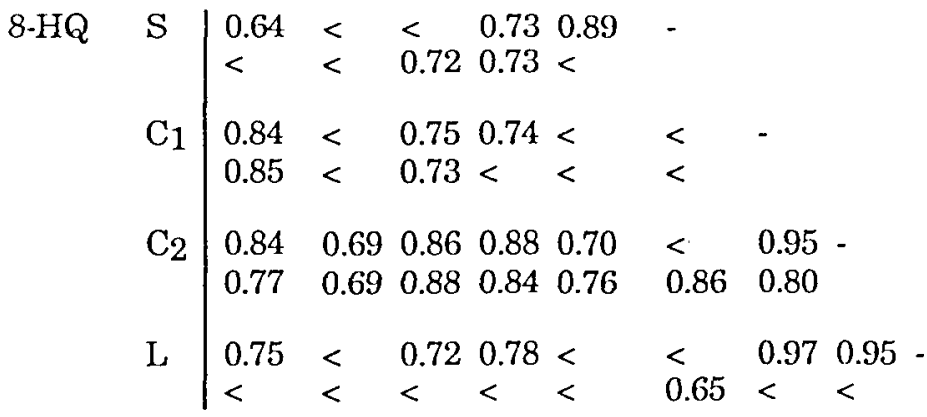

\begin{tabular}{ll|llllllllll} 
Resin & $S$ & 0.87 & 0.68 & 0.83 & 0.81 & 0.64 & $<$ & 0.97 & 0.98 & 0.93 & -
\end{tabular} $0.76<0.670 .770 .65<<0.73<$

$$
\begin{array}{ll}
\mathrm{S} & =\text { Soil Solution } \\
\mathrm{B} & =1: 100.1 \mathrm{M} \mathrm{BaCl}_{2} \\
\mathrm{C}_{1} & =1: 50.0017 \mathrm{M} \mathrm{CaCl}_{2} \\
\mathrm{C}_{2} & =1: 50.01 \mathrm{M} \mathrm{CaCl}_{2} \\
\mathrm{~L} & =1: 50.00083 \mathrm{M} \mathrm{LaCl}_{3} \\
< & =\mathrm{r}^{2} \text { less than } 0.64
\end{array}
$$


to the left as the $\mathrm{Al}^{3+}$ is removed from solution.

Forms of Al Extracted by Resins: The fraction of total aluminum removed by both exchange resins was greater than that attributable to $\mathrm{Al}^{3+}$ and included $\mathrm{Al}$ which would have been in the form of both inorganic and organic (humate) complexes before the resin was added. In experiments $\mathrm{A}$ and $\mathrm{C}$ most of the $\mathrm{Al}$ in solution was taken up by the resins very quickly even though hydroxy and sulphate complexes of $\mathrm{Al}$ were present. Campbell et al. (6) found that inorganic complexing of $\mathrm{Al}$ by $\mathrm{OH}^{-}$and $\mathrm{F}$ had little effect on the proportion of $\mathrm{Al}$ removed from solution by Chelex-100.

Removal of $\mathrm{Al}$ by the resins from Al-humate solutions (experiments $\mathrm{A}$ and $\mathrm{B}$ ) was much slower than from solutions containing only inorganic ligands. This suggests that dissociation of Al-humate occurred before uptake by the resin and that resins can compete with soluble ligands that have a high affinity for $\mathrm{Al}$ as long as the complex dissociates very readily. Campbell et al. (6) found that Chelex-100 removed $10 \%$ of total soluble $\mathrm{Al}$ in the presence of $20 \mathrm{mg} / \mathrm{L} \mathrm{HA}$ at $\mathrm{pH}$ 5.0. This slightly smaller proportion in comparison with our results could be due to the higher $\mathrm{pH}$ used in their work increasing the complexing capacity of the humic acids compared with that at $\mathrm{pH} 4.5$ used in our work. For example, Ritchie et al. (4) found that humate could compete more effectively with fluoride for Al at $\mathrm{pH} 6$ than at $\mathrm{pH} 4$.

There seems little scope for using cation-exchange resins in this manner to predict the phytotoxicity of $\mathrm{Al}$ in the presence of sufficiently high concentrations of inorganic ligands such as $\mathrm{F}$ and $\mathrm{SO}^{2}$, which have been shown to reduce $\mathrm{Al}$ toxicity in barley seedlings (2).

\section{Comparison of Al Removed from Humic Acid Solutions by Chelex-100 Resin}

and 8-Hydroxyquinoline: 8-HQ extracted a greater proportion of Al-tot than did Chelex-100 from the Al-humate solutions (experiment D). As the ratio of molc of Al:HA increased, the ability of both methods to extract Al decreased (Figure 5), possibly because Al-humate polymers and/or colloids had formed and thus decreased the proportion of rapidly labile $\mathrm{Al}$. 
Exclusion of large molecules from the pores of the Chelex-100 (18) and the ability of 8-HQ to mix more intimately than Chelex-100 with polymers and fine colloids could account for the large difference between these two methods at high Al:HA ratios. This could be relevant to (centrifuged) soil solutions, even when they are filtered through $0.45 \mu \mathrm{m}$ for analysis, and therefore choice of method of measuring rapidly labile Al may be important in attempting to measure phytotoxic $\mathrm{Al}$ in the presence of organic ligands over a range of $\mathrm{Al}$ :organic ligand ratios.

\section{Labile Al in Humic Acid Solutions and the Soil Solution of Peaty Sands and}

Peat-Sand Mixtures: In soil solutions of peaty sand the proportion of $\mathrm{Al}$ extracted by Chelex-100 was greater than that extracted by 8-HQ (Figure 8a) but was approximately the same in the sand-peat mixture with a similar organic $\mathrm{C}$ content (Figure 6a). This contrasts with the humic acid solutions in which Al-HQ was greater than Al-res (Figure 5). A comparison of the proportions of $\mathrm{Al}$ extracted by each method plotted against the ratio of $\mathrm{Al}(\mu \mathrm{M}): \mathrm{C}(\mathrm{mg} / \mathrm{L})$ in the humic acid and soil solutions indicated that Chelex-100 extracted a greater proportion of $\mathrm{Al}$ from the soil solutions of peaty sands than from humic acid and the soil solutions of sand-peat mixtures, while 8-HQ extracted more $\mathrm{Al}$ from humic acid solutions than from both types of soil solution (Figure 5). Both Chelex-100 and 8-HQ extracted more labile $\mathrm{Al}$ from the peaty sands than from the sand-peat mixture.

The interaction between the method of measuring labile Al and the source of organic matter is not explained by this experiment. Some possible explanations can be eliminated. The difference in mesh size and form of Chelex-100 used ( $\mathrm{Ca} / \mathrm{H}$ form, 50-100 mesh for $\mathrm{HA} ; \mathrm{Mg} / \mathrm{H}$ form, 100-200 mesh for soil solution) could explain the difference between peaty sands and humic acid. However, the greater proportion of $\mathrm{Al}$ extracted from solutions containing humic acid by the larger diameter resin (experiment $\mathrm{A}$ ) compared with that taken up by the smaller diameter resin used by Campbell et al. (6) indicates that some factors other than size of resin particle are controlling the amount of $\mathrm{Al}$ which can exchange with Chelex-100 at any particular $\mathrm{pH}$. 
The higher proportion of Al-res at any particular $\mathrm{Al}(\mu \mathrm{M}): \mathrm{C}(\mathrm{mg} / \mathrm{L})$ ratio in the soil solution of the peaty sands compared with that in the sand-peat mixtures or the humic acid solutions (Figure 5a) may be due to a higher proportion of $\mathrm{Al}$ complexes in the peaty sands with molecular weights low enough to exchange more readily than Al-humate with Chelex-100. The acid-leaching process may have removed most of the low molecular weight ligands from the peat, so that $\mathrm{Al}$ humate and $\mathrm{Al}$-fulvate, which exchange at similar rates with Chelex-100 (6), were the predominant forms of organically complexed $\mathrm{Al}$ in the sand-peat mixtures. Although Hodges (19) reported that in solutions containing $\mathrm{Al}(8-80 \mu \mathrm{M})$ and citrate (1mM) at $\mathrm{pH} 4.2, \mathrm{Al}$ passed through columns of Rexyn 101, his results are inconclusive because the columns were reused without removing $\mathrm{Al}$ accumulated from previous samples. This work has shown that $\mathrm{Al}$ complexed with small organic ligands may be taken up by Chelex-100 as completely as is $\mathrm{Al}$ which is complexed with $\mathrm{OH}^{-}$or $\mathrm{F}^{-}(6)$ and $\mathrm{OH}^{-}$or $\mathrm{S}_{4}{ }^{2-}$.

The increasing proportion of $\mathrm{Al}-\mathrm{HQ}$ at any $\mathrm{Al}(\mu \mathrm{M}): \mathrm{C}(\mathrm{mg} / \mathrm{L})$ ratio in the soil solutions of sand-peat mixtures, peaty sands, and the humic acid solutions, respectively (Figure 5b), corresponds with a decrease in $\mathrm{Al}$ and $\mathrm{C}$ concentrations (data not shown). This inverse relationship between the concentrations of $\mathrm{Al}$ and $\mathrm{C}$ and the proportion of Al-HQ but not Al-res at a constant $\mathrm{Al}(\mu \mathrm{M}): \mathrm{C}(\mathrm{mg} / \mathrm{L})$ ratio suggests that the organic ligands are interfering with the 8-HQ assay in a way which is independent of the proportion of $\mathrm{Al}$ complexed with the ligands. This could occur if the organic ligands interfered with the formation of the Al-HQ complex and/or decreased the extraction of Al-HQ into the butyl acetate when the reaction is quenched. Controls for colour interference in the spectrophotometric determination of Al-HQ indicated that no soil organic matter or humic acid was extracted into the butyl acetate when 8-HQ was omitted from the assay solution.

\section{Aluminum-Organic Matter Reactions in Sand-Peat Mixtures: At a constant $\mathrm{pH}$,} Al-tot in the soil solution of the sand-peat mixtures was a function of soluble organic matter, whereas Al-tot in the salt extracts was also controlled by the presence of the salt cation. Ritchie et al. (20) found that calcium could precipitate 
humic acid by electrostatic attraction at molc of calcium:humate $<1$, whereas $\mathrm{Al}$ precipitated humic acid by complexing at molc of $\mathrm{Al}$ : humate $>1$.

At a constant $\mathrm{pH}$ and high peat additions ( $>1 \%$ ), Al-tot in $\mathrm{CaCl} 2, \mathrm{BaCl}$, and $\mathrm{LaCl} 3$ extracts are not good indicators of Al-organic matter complexing in the soil solution because the cation of the salt solution can cause soluble organic matter to precipitate and hence change the extent of complexing between $\mathrm{Al}$ and organic ligands. Al-HQ in the soil solution was not well correlated with Al-HQ in the $\mathrm{CaCl} 2$ and $\mathrm{LaCl} 3$ solutions, whereas $\mathrm{Al}$-res was linearly related with $\mathrm{Al}-\mathrm{HQ}$ in the salt extracts.

The poor correlation between Al-HQ in the soil solutions and that in the 1:5 extracts may be due to overestimation of organically complexed $\mathrm{Al}$ in the soil solutions with high concentrations of $\mathrm{Al}$ and organic $\mathrm{C}$ (because of possible interference as outlined above) and underestimation of organically complexed $\mathrm{Al}$ in the 1:5 extracts where the equilibrium has been disturbed by the extracting cation.

The good correlation between Al-res and Al-HQ in the extracts suggests that both these methods underestimate the proportion of $\mathrm{Al}$ which is organically complexed. Nevertheless, Al-HQ in the soil solution may still be a better estimation of toxic Al than ion exchange resin, provided the concentration of potentially interfering organic compounds is low.

Al-Organic Matter Reactions in Soils: The concentration of Al in solution was affected by $\mathrm{pH}$, the presence of $\mathrm{Ca}$, and adsorption of $\mathrm{Al}$. The amount of $\mathrm{Al}$ in 1:5 extracts in salt solutions was only proportional to that in the soil solution when $\mathrm{Ca}$ did not precipitate organic ligands or when the $\mathrm{pH}$ of the extract changed in a similar manner to that in the soil solution.

The addition of $\mathrm{Al}$ to the Gavin soil caused a marked increase in $\mathrm{Al}$ in the soil solution even though $\mathrm{pH}$ and soluble $\mathrm{C}$ remained reasonably constant. The increase in $\mathrm{Al}$ concentration was presumably because of a lack of adsorption sites. In the $\mathrm{CaCl} 2$ extracts, there was little change in $\mathrm{Al}-$ tot or $\mathrm{Al}-\mathrm{HQ}$ with $\mathrm{Al}$ addition and soluble $\mathrm{C}$ increased only at the highest $\mathrm{Al}$ addition, possibly because $\mathrm{Ca}$ was 
precipitating soluble organic matter until the $\mathrm{Al}$ concentration was high enough to compete with the $\mathrm{Ca}$ to form a soluble organic complex.

In the two Joel soils, the variation of Al-tot, $\mathrm{Al}-\mathrm{HQ}$, and $\mathrm{C}$ with addition of $\mathrm{Al}$ was fairly similar in the soil solution and the $\mathrm{CaCl} 2$ extracts. Soluble $\mathrm{C}$ was much higher than in the Gavin soil and hence there was probably insufficient $\mathrm{Ca}$ to cause precipitation of soluble organic matter.

The major factor controlling soluble $\mathrm{Al}$ in the soil solution of the Mungite soil appeared to be $\mathrm{pH}$. In the $\mathrm{CaCl} 2$ extracts, however, the effect of $\mathrm{pH}$ may have been decreased by the presence of $\mathrm{Ca}$. Even though the $\mathrm{pH}$ in the extracts increased with $\mathrm{Al}$ added, $\mathrm{Al}$-tot did not decrease as much as could be expected from the $\mathrm{pH}$ change. This may have been due to precipitation of organic matter by $\mathrm{Ca}$ at the lower additions of $\mathrm{Al}$ limiting the formation of organic $\mathrm{Al}$ complexes. As more $\mathrm{Al}$ was added, it was able to successfully compete with the $\mathrm{Ca}$ to form a soluble complex with organic ligands and hence the Al concentration did not decrease as much as may be expected from the concurrent drop in $\mathrm{pH}$.

\section{CONCLUSION}

Aluminum that reacts with 8-HQ and with resins includes forms that are thought not to be toxic to plants. The forms of $\mathrm{Al}$ extracted by large volumes of salt solutions are not necessarily equivalent to the forms in the soil solution because the extracting cation may cause precipitation of a ligand with which some of the Al would have been complexed and hence would become non-toxic. The concentration and form of $\mathrm{Al}$ after it has been added to soils is controlled by $\mathrm{pH}$, adsorption, and precipitation.

\section{ACKNOWLEDGEMENTS}

We are indebted to Janine Catchpole for her contribution in the laboratory and to David Faithful and Bill Simmons for assistance with analysis by ICP and GFAAS, respectively. 


\section{REFERENCES}

1. Blamey, F. P. C., D. G. Edwards, and C. J. Asher. 1983. Effects of aluminum, OH:Al and $\mathrm{P}: \mathrm{Al}$ ratios, and ionic strength on soybean root elongation in solution culture. J. Soil Sci 136:197-207.

2. Cameron, R. S., G. S. P. Ritchie, and A. D. Robson. 1986. Relative toxicities of inorganic aluminum complexes to barley. Soil Sci. Soc. Am. J. 50:1231-1236.

3. Hue, N.V., G. R. Craddock, and F. Adams. 1986. Effect of organic acids on aluminum toxicity in subsoils. Soil Sci. Soc. Am. 50:28-34.

4. Ritchie, G. S. P., M. P. Nelson, and M. G. Whitten. 1988. The estimation of free aluminum and the competition between fluoride and humate anions for aluminum. Comm. Soil Sci. Plant Anal. 19:857-871.

5. Moore, C. S., and G. S. P. Ritchie. 1988. Aluminum speciation and pH of an acid soil in the presence of fluoride. J. Soil Sci. 39:1-8.

6. Campbell, P. G. C., M. Bisson, R. Bougie, A. Tessier, and J. P. Villeneuve. 1983. Speciation of aluminum in acidic fresh-waters. Anal. Chem. 55:22462252.

7. Posner, A. M. (1966). The humic acids extracted by various reagents from a soil. J. Soil Sci. 17:65-78.

8. Figura, P., and B. McDuffie. 1979. Use of chelex resin for determination of labile trace metal fractions in aqueous ligand media and comparison of the method with anodic stripping voltammetry. Anal. Chem. 51:120-125.

9. Westall, J. 1979. MICROQL I. A chemical equilibrium program in BASIC. Int. Rep. Swiss Federal Institute of Technology, Zurich.

10. Ritchie, G. S. P., and S. C. Jarvis. 1986. Effects of inorganic speciation on the interpretation of copper adsorption by soils. J. Soil Sci. 37:205-210.

11. Lindsay, W. L. 1979. Chemical equilibria in soils. John Wiley and Sons, New York.

12. James, B.R., C. J. Clarke, and S. J. Riha. 1983. An 8-hydroxyquinoline method for labile and total aluminum in soil extracts. Soil Sci. Soc. Am. J. 47:893-897. 
13. Northcote, K. H. 1979. A factual key for the recognition of Australian soils. Rellim Technical Publications, Adelaide.

14. Bettenay, E., W. M. McArthur, and F. J. Hingston. 1960. The soil associations of the Swan Coastal Plain, Western Australia. CSIRO Aust. Soils and Land Use Ser. No. 35.

15. Gillman, G. P. 1976. A centrifuge method for obtaining soil solution. CSIRO Aust. Div. Soils, Div. Rep. No. 16.

16. Smith, R. 1952. The soils of the South West Australian Agricultural Region. Thesis [D.Sc.(Agric.)]. University of Western Australia.

17. Bio-Rad. 1976. Chelex ${ }^{\mathrm{TM}} 100$ chelating ion exchange resin for analysis, removal or recovery of trace metals. Bio-Rad Laboratories, Richmond, CA. Bulletin 2020.

18. Florence, T. M. 1982. The speciation of trace elements in waters. Talanta 29:345-364.

19. Hodges, S.C. 1987. Aluminum speciation: A comparison of five methods. Soil Sci. Soc. Am. J. 51:57-64.

20. Ritchie, G. S. P., R. G. McLaren, and R. S. Swift. 1990. The precipitation of humic acids by aluminum and calcium. (In prep.) 